\title{
Range extension of Centronycetris maximiliani (Mammalia: Chiroptera) for southern Amazonia
}

\author{
Patrício A. da ROCHA ${ }^{1 *}$, Marcus V. BRANDÁO², Adalberto Césari de OLIVEIRA JÚNIOR ${ }^{3}$, \\ Caroline Cotrim AIRES ${ }^{4}$ \\ 1 Universidade Federal da Paraíba, Programa de Pós-Graduação em Zoologia, Campus I, Departamento de Sistemática e Ecologia, CEP 58.059-900. Jardim Universitário, João \\ Pessoa, Paraíba, Brazil. \\ 2 Universidade Federal de São Carlos, Programa de Pós-Graduação em Diversidade Biológica e Conservação, Campus Sorocaba, Departamento de Biologia, CEP: 18052-780. Itinga, \\ Sorocaba, São Paulo, Brasil. \\ ${ }^{3}$ Universidade de São Paulo, Museu de Zoologia, CEP 042630-00. Ipiranga, São Paulo, São Paulo, Brasil. \\ ${ }^{4}$ Universidade de Mogi das Cruzes, Campus da Sede, CEP 087809-11. Vila Partenio, Mogi das Cruzes, São Paulo,] Brazil. \\ *Corresponding author: parocha2@yahoo.com.br
}

\section{ABSTRACT}

Bat species of the genus Centronycteris are some of the rarest Neotropical Emballonuridae and fewer than 50 specimens have been deposited in scientific collections. The aim of this study is to extend the distribution of Centronycteris maximiliani. Three C. maximiliani specimens were recorded in the Brazilian Amazonia, providing the first record of the species for the state of Rondônia, the southernmost record of the species for the Amazon biome in Brazil, and an additional record for the state of Pará. Although these new records of $C$. maximiliani reinforce the idea that this species is widely distributed throughout the Amazon biome, its low capture rate reflects the rarity of this species, since only three specimens were collected during three to four year field effort.

KEYWORDS: Emballonuridae, distribution, rainforest, Brazil.

\section{Extensão de distribuição geográfica de Centronycetris maximiliani (Mammalia: Chiroptera) para o sul da Amazonia}

\section{RESUMO}

Espécies de morcegos do gênero Centronycteris são alguns dos mais raros Emballonuridae Neotropicais e menos de 50 espécimes foram depositados em coleçóes científicas. O objetivo deste estudo é estender a distribuição de Centronycteris maximiliani. Três espécimes de $C$. maximiliani foram registrados na Amazônia Brasileira, proporcionando o primeiro registro da espécie para o estado de Rondônia, o registro mais austral da espécie para o bioma Amazônia no Brasil, e um registro adicional para o Estado do Pará. Embora esses novos registros de $C$. maximiliani reforcem a idéia de que esta espécie é amplamente distribuída por todo o bioma amazônico, a sua baixa taxa de captura reflete a raridade da espécie, uma vez que apenas três espécimes foram coletados durante três a quatro anos de esforço de campo.

PALAVRAS-CHAVE: Emballonuridae, distribuição, floresta tropical, Brasil. 
The pantropical sheath-tailed bat family Emballonuridae reaches its highest diversity at the Neotropical region (Koopman 1994), where it is represented by the tribe Diclidurini (Lim et al. 2008). A total of eight genera and 21 species of Emballonuridae are known for the Neotropics; however, the region remains poorly explored and distributional data is scarce for most species (Hood and Gardner 2008, Bernard et al. 2011).

Bat species of the genus Centronycteris are some of the rarest Neotropical Emballonuridae and fewer than 50 specimens have been deposited in scientific collections around the world by late twentieth century (Simmons and Handley 1998). This genus is currently composed of only two species, Centronycteris centralis Thomas, 1912 and Centronycteris maximiliani (Fischer, 1829), both restricted to the rainforests (Hood and Gardner 2008).

Based on morphology, Simmons and Handley (1998) validated Centronycteris centralis - previously considered by Sanborn (1937) a subspecies of C. maximiliani - which is now known from southern Mexico, east of Central America, Ecuador, Colombia and Peru. Thus those authors restricted the distribution of $C$. maximiliani to northern Peru, eastern Colombia, southern Venezuela, Guyana, French Guiana, Suriname, the central Amazon basin, and Atlantic coastal forests of Brazil (Simmons and Handley 1998; Hood and Gardner 2008). The aim of the present work was to extend the distribution of $C$. maximiliani in the Brazilian Amazonia. The three specimens reported herein were collected in faunal surveys carried out in the Amazonian region, between the years 2008 and 2010, with mist-nets, set on ground level, providing the first record of the species for the state of Rondônia, the southernmost record of the species for the Amazon biome in Brazil, and an additional record for the state of Pará.

The two males (MZUSP 35002, MZUSP 35003) were captured near the margins of Médio Rio Madeira, located in the Caiçara district, municipality of Porto Velho, state of Rondônia (9'28'S, 64\% $\left.49^{\prime} \mathrm{W}\right)$ and one lactating female (MZUSP 35368) was collected at "Igarapé Mano", located in the city of Marabá, state of Pará ( $5^{\circ} 46^{\prime} \mathrm{S}, 50^{\circ} 30^{\prime} \mathrm{W}$ ) (Figure 1). The latter was caught in a mist-net placed in front of the exit of its diurnal roost, a tree cavity located at approximately $1.8 \mathrm{~m}$ from the ground, in which no other bats were detected. Both areas are covered by the Alluvial Ombrophilous Dense Forest, a vegetation type characterized by medium and large trees, palms, woody vines, and epiphytes.

The specimens were handled in accordance with Sikes et al. (2011). They were fixed in formaldehyde $10 \%$ and preserved in ethanol 70\%. The skull of MZUSP 35002 and 35003 was extracted. After ecording external and cranial measurements, (Table 1) all three specimens were deposited at Museu de Zoologia da Universidade de São Paulo, São Paulo, Brazil
(MZUSP). External and cranial measurements (in millimeter) were taken as described by Simmon and Handley (1998).

Centronycteris can be distinguished from other Emballonuridae genera by the following set of characters: i) fur extends beyond the body onto both surfaces of the uropatagium; ii) dorsal fur is bicolored with dark gray-brown bases that blend gradually into paler brown or brownishorange tips, ventral fur is slightly paler than dorsum and sharply bicolored, with fuscous bases and paler brown tips; iii) absence of dorsal stripes and wing sac; iv) wing attached to the metatarsals near base of toes; v) basisphenoid pit divided by well-developed median septum; vi) basioccipital longer than its minimum width; and vii) upper anterior premolar tricuspidate (Jones and Hood 1993; Simmons and Handley 1998; Hood and Gardner 2008). According to Simmons and Handley (1998) C. maximiliani differs from C. centralis in presenting: i) basisphenoid pit weakly divided into anterior and posterior sections with anterior section extending forward between pterygoid processes; ii) posterolateral margins of palate smoothly curved, without notches; iii) rostrum with dorsolateral swelling at base of postorbital process; iv) nasals constricted anteriorly (between medially expanded maxillae) and terminate at level of anterior borders of orbit; v) maxillary tooth row with a procumbent upper canines, a minute anterior upper pre-molar (about one-fourth of the posterior upper pre-molar), and a large gap between upper pre-molars (equal/ larger than the crown length of anterior upper pre-molar); vi) robust mandible with an ascending ramus of coronoid process that rises in a gentle curve from immediately behind the last lower molar (Figure 2).

According to the present work and to the records summarized by Simmons and Handley (1998), the occurrence of $C$. maximiliani has been recorded in 26 localities, from which, three are located in the Atlantic Forest, whereas the other 23 are located in the Amazon region. The presence of this species in the Brazilian state of Rondônia extends the distribution quite considerably, reaching the southern portion of Amazonia (Figure 1), 680 kilometers away from its previous southernmost location. Although these new records of C. maximiliani reinforce the idea that this species is widely distributed throughout the Amazon biome, its low capture rate reflects the rarity of this species, since only three specimens were collected during three to four year field effort. Therefore this data corroborates Arita (1993), who categorized it as a rare but widely distributed species. Considering that the previous record of $C$. maximiliani occurred at Atlantic Forest by Deoclécio Guerra, in 1978 (UFPE 768), this could indicates that it might be even rarer in this biome.

Its wide distribution throughout two of the largest South American forests and the absence of records in dry forests (e.g. Chaco, Cerrado, and Caatinga) suggest the preference of this 


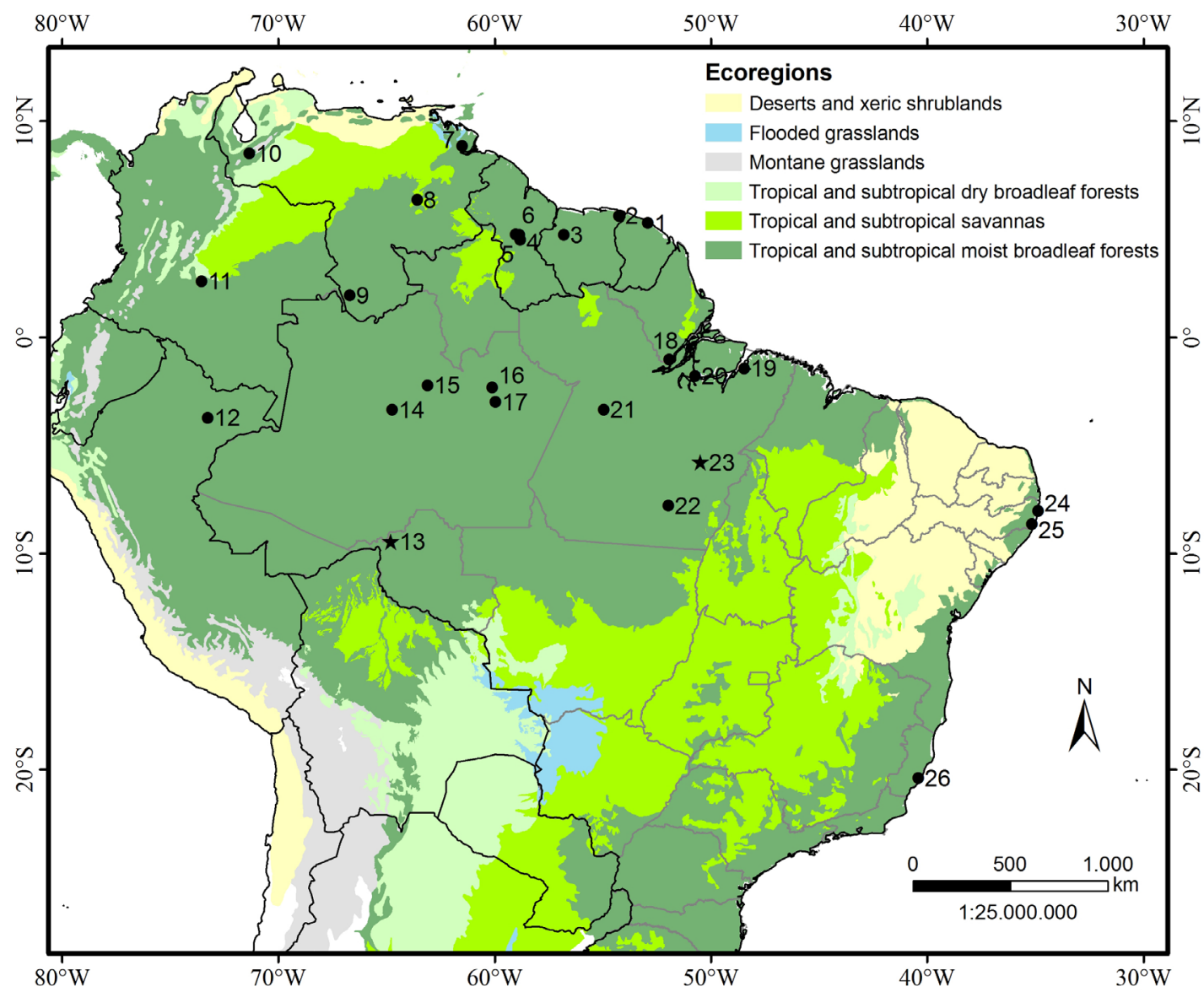

Figure 1. Geographic distribution of Centronycteris maximiliani (circles) and the new records (stars). For code numbers of localities, see Table 2.

Table 1. Body and cranial measurements of the Centronycteris maximiliani specimens collected during the present study and specimens from Simmons and Handley (1998). (a): Measurements are given in millimeters, except for weight that is given in grams; (b): Range (sample size).

\begin{tabular}{|c|c|c|c|c|c|}
\hline \multirow{3}{*}{ Measurements ${ }^{a}$} & \multicolumn{3}{|c|}{ Present Study ${ }^{a}$} & \multicolumn{2}{|c|}{ Simmons and Handley (1998) } \\
\hline & MZUSP & MZUSP & MZUSP & \multirow{2}{*}{$\lesssim(n)$} & \multirow{2}{*}{$q$ (n) } \\
\hline & $35002-\hat{O}$ & $35003-\hat{O}$ & $35368-+q$ & & \\
\hline Weight $(\mathrm{g})$ & 5 & 6 & 5 & $4.5(1)$ & $5.0-9.0(4)$ \\
\hline Tail length & 19.8 & 21.5 & 19.0 & $26.0(1)$ & $20.0-23.0(2)$ \\
\hline Hind foot length & 6.15 & 6.25 & 6.4 & $7.0(1)$ & $6.0-8.0(6)$ \\
\hline Ear length & 17.75 & 18 & 18.1 & $17.0(1)$ & $14.00-17.0(4)$ \\
\hline Forearm length & 43.5 & 44.4 & 43.9 & $41.5(1)$ & $42.2-44.7(7)$ \\
\hline Tibia length & 18.8 & 19 & 18.7 & $16.6(1)$ & $17.0-18.3(8)$ \\
\hline Condylocanine length & 14.8 & 14.1 & & $13.38-14.11(2)$ & $12.8-14.39(6)$ \\
\hline Basisphenoid pit length & 2.8 & 2.6 & & $2.76-2.85(2)$ & $2.5-3.14(5)$ \\
\hline Interorbital breadth & 2.95 & 2.98 & & $2.95-3.30(2)$ & $2.9-3.2(7)$ \\
\hline Lacrimal breadth & 6.4 & 6.38 & & $6.42-6.66(2)$ & $6.07-6.64(5)$ \\
\hline Zygomactic breadth & 9.1 & 9.1 & & $8.93(1)$ & $8.7-9.31(7)$ \\
\hline Mastoid breadth & 7.9 & 7.7 & & $7.29-8.09(2)$ & $7.27-8.03(6)$ \\
\hline Maxillary toothrow length & 6.1 & 6.0 & & $5.57-5.67(2)$ & $5.62-6.00(7)$ \\
\hline Breadth across molars & 6.75 & 6.7 & & $6.73(1)$ & $6.2-6.77(7)$ \\
\hline Length of lower molar row & 3.74 & 3.78 & & $3.71-4.07(3)$ & $3.59-3.9(5)$ \\
\hline
\end{tabular}


Table 2. Locality records for Centronycteris maximiliani in Brazil and in other South American countries. The code numbers refer to the points shown in Figure 1.

\begin{tabular}{|c|c|c|c|c|}
\hline \multirow{2}{*}{ Country/ Point } & \multicolumn{2}{|c|}{ Coordinates } & \multirow{2}{*}{ Locality } & \multirow{2}{*}{ Reference } \\
\hline & Lat y & Long $x$ & & \\
\hline \multicolumn{5}{|c|}{ FRENCH GUIANA } \\
\hline 1 & 5.28333333 & -52.91666667 & Paracou Field Station & $\begin{array}{c}\text { Simmons and Handley (1998); Simmons and } \\
\text { Voss (1998) }\end{array}$ \\
\hline \multicolumn{5}{|l|}{ SURINAM } \\
\hline 2 & 4.73333333 & -56.8 & Bakhuis & $\operatorname{Lim}(2009)$ \\
\hline 3 & 5.61666667 & -54.25 & Marowijine & Williams et al. (1983) \\
\hline \multicolumn{5}{|l|}{ GUYANA } \\
\hline 4 & 4.5 & -58.81666667 & Iwokrama Forest - Potaro-Siparuni & Lim and Engstrom (2001) \\
\hline 5 & 4.75 & -59.01666667 & Pakatau Falls - Potaro-Siparuni & Lim et al. (1999) \\
\hline 6 & 4.73333333 & -58.85 & Clearwater Camp - Potaro-Siparuni & Lim et al. (1999) \\
\hline \multicolumn{5}{|l|}{ VENEZUELA } \\
\hline 7 & 1.93333333 & -66.7 & Amazonas - Buena Vista & $\begin{array}{l}\text { Simmons and Handley (1998); McCarthy and } \\
\text { Ochoa (1991) }\end{array}$ \\
\hline 8 & 6.35 & -63.58333333 & Bolívar & Lim and Tavares (2012) \\
\hline 9 & 8.85 & -61.5 & Delta Amacuro & Lim and Tavares (2012) \\
\hline 10 & 8.5 & -71.35 & San Juan, Mérida & Lim and Engstrom (2001) \\
\hline \multicolumn{5}{|l|}{ COLOMBIA } \\
\hline 11 & 2.58333333 & -73.55 & Serranía de La Macarena, Meta & Cuervo-Díaz et al. 1986 \\
\hline \multicolumn{5}{|l|}{ PERU } \\
\hline 12 & -3.7333333 & -73.26666667 & Iquitos, Loreto & Hice et al. (2004); Hice and Solari (2002) \\
\hline \multicolumn{5}{|l|}{ BRAZIL } \\
\hline 13 & -9.4666667 & -64.81666667 & PortoVelho - RO & This study \\
\hline 14 & -3.3666667 & -64.73333333 & Tefé - AM & Simmons and Handley (1998); Sanborn (1937) \\
\hline 15 & -2.2333333 & -63.1 & Jaú National Park - AM & Barnett et al.(2006) \\
\hline 16 & -2.3333333 & -60.11666667 & $\begin{array}{l}\text { Biological Dynamics of Forest Fragments Project, } \\
\text { AM }\end{array}$ & Simmons and Handley (1998); Bernard (2001) \\
\hline 17 & -3 & -59.95 & Manaus - AM & Reis (1984) \\
\hline 18 & -1.0333333 & -51.93333333 & Amapa National Forest - AP & Martins et al.(2006) \\
\hline 19 & -1.45 & -48.46666667 & Belém - PA & Simmons and Handley (1998) \\
\hline 20 & -1.8 & -50.71666667 & Estação Científica Ferreira Penna - Melgaço- PA & Marques-Aguiar et al.(2003) \\
\hline 21 & -3.35 & -54.95 & Tapajos National Forest - PA & Castro-Arellano et al. (2007) \\
\hline 22 & -7.8 & -51.96666667 & $\begin{array}{c}\text { Kayapó Center for Ecological Research (Pinkaití), } \\
\text { Pará }\end{array}$ & Peters et al.(2006) \\
\hline 23 & -5.8 & -50.5 & Marabá - PA & This study \\
\hline 24 & -8.0333333 & -34.86666667 & Recife - PE & Simmons and Handley (1998) \\
\hline 25 & -8.65 & -35.15 & Rio Formoso - PE & UFPE 768 \\
\hline 26 & -20.4 & -40.4 & $\begin{array}{l}\text { Rio Jucú, Fazenda Coroaba (holotype of Vesperti- } \\
\text { lio calcarata) - ES }\end{array}$ & Simmons and Handley (1998) \\
\hline
\end{tabular}

species for humid forest environments. Thus, its scarce records in the Atlantic Forest may characterize a disjunct distribution pattern, with two distinct population groups.

Graham (1987) proposes that, in the Amazon Basin, Emballonuridae bats start reproducing in the wet season. Hice and Solari (2002) reported one pregnant female in September and one lactating female in November, both captured in Peru. The lactating female described herein was captured in the state of Pará in the dry season, which suggests that Centronycteris is polyestrus, as there are a number of other bat species from the tropics (Neuweiler, 2000).

The examination of the reproductive tract of the female MZUSP 35368 showed a bicornuate uterus, with a fetus in the early stage of development in its left side. Other Emballonuridae also present bicornuate uterus, such as Peropteryx kappleri (Rasweiler 1982) and Rhynchonycteris naso 


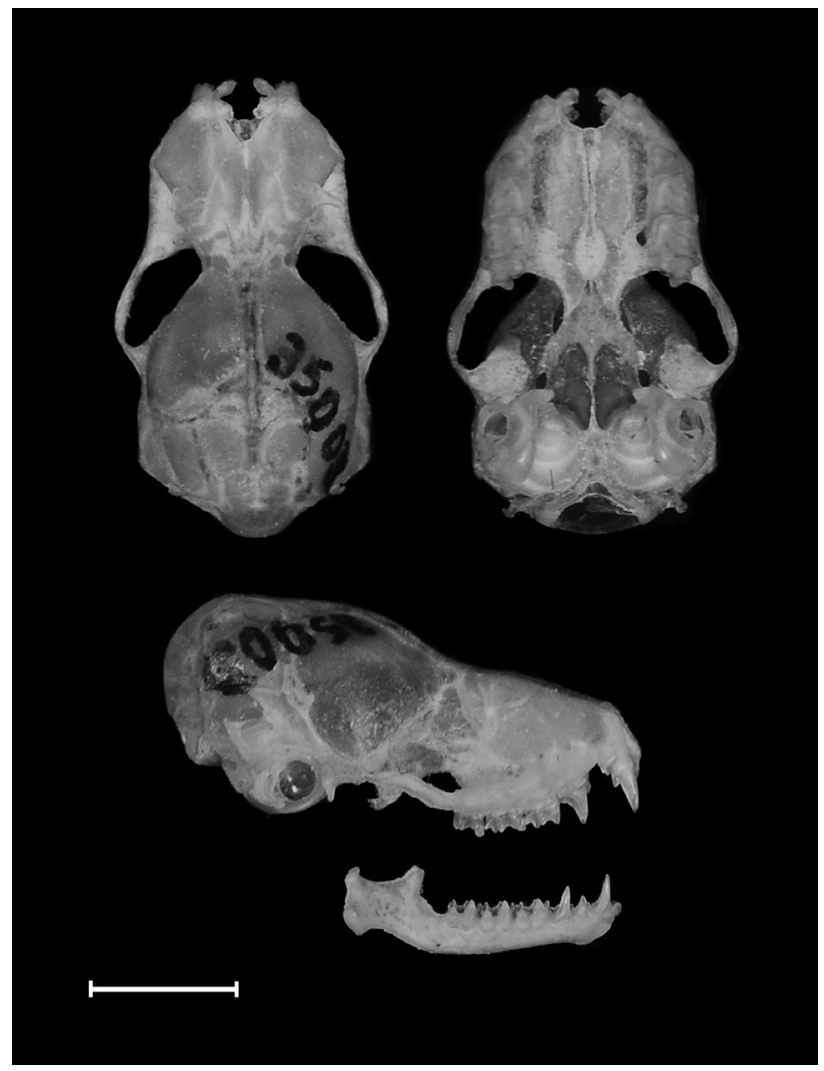

Figure 2. Dorsal, ventral and lateral views of the skull and a lateral view of the mandible of Centronycteris maximiliani (MZUSP 35003). Scale bar: $5 \mathrm{~mm}$.

(Carter and Mess 2008), which according to Carter and Mess (2008) it is also found in many species of bats. The authors posit that this type of uterus presents uterine horns that join internally to form the body, which communicates with the vagina through a common cervical canal.

\section{ACKNOWLEDGMENTS}

We are grateful to Arcadis Logos S/A and to Habtec Engenharia Sanitária e Ambiental Ltda.; to Juliana GualdaBarros and to Dr. Mario de Vivo, for the access to the specimens in the MZUSP Mammal Collection; to Dr. Stephen Francis Ferrari for the careful review of the manuscript. PAR thanks CAPES for the graduate scholarship and to CNPq (501701/2013-3) for the research grants.

\section{REFERENCES}

Arita, H.T. 1993. Rarity in Neotropical bats: correlations with phylogeny, diet, and body mass. Ecological Applications 3: 506-517.

Barnett, A.A.; Sampaio, E.M.; Kalko, E.K.V.; Shapley, R.L.; Camargo, G.; Rodriguez Herrera, B. 2006. Bats of Jaú National Park, central Amazônia, Brazil. Acta Chiropterologica 8:103-128.
Bernard, E. 2001. Vertical stratification of bat communities in primary forests of Central Amazon, Brazil. Journal of Tropical Ecology 17:115-126.

Bernard, E.; Tavares, V.C.; Sampaio, E. 2011. Compilação atualizadas das espécies de morcegos (Chiroptera) para a Amazônia brasileira. Biota Neotropica 11:35-46.

Carter, A.M.; Mess, A. 2008. Evolution of the placenta and associated reproductive characters in bats. Journal of Experimental Zoology 310:428-449.

Castro-Arellano, I.; Presleya, S.J.; Saldanha, L.N.; Willig, M.R.; Wunderle, J.M. 2007. Effects of reduced-impact logging on bat biodiversity in terra firme forest of lowland Amazonia. Biological Conservation 138:269-285.

Cuervo-Díaz, A.; Hernández-Camacho, J.; Cadena, A. 1986. Lista actualizada de los mamíferos de Colombia: anotaciones sobre su distribución. Caldasia 15:471-502.

Graham, G.L. 1987. Seasonality of reproduction in Peruvian bats. Fieldiana Zoology. 39:173-186.

Hice, C.L.; Solari, S. 2002. First record of Centronycteris maximiliani (Fisher, 1829) and two additional records of $C$. centralis Thomas, 1912 from Peru. Acta Chiropterologica. 4:217-20.

Hice, C.L.; Velazco, P.M.; Willig, M.R. 2004. Bats of the Reserva Nacional Allpahuayo-Mishana, northeastern Peru, with notes on community structure. Acta Chiropterologica 6: 319-334.

Hood, C.; Gardner, A.L. 2008. Family Emballonuridae Gervais, 1856. In Gardner, A.L. (Ed.). Mammals of South America. v.1.: Marsupials, Xenarthrans, Shrews and Bats. Chicago: The University of Chicago Press, p. 188-207

Jones Jr., J.K.; and Hood, C.S. 1993. Synopsis of South American bats of the family Emballonuridae. Occasional Papers, The Museum, Texas Tech University 155: 1-32.

Koopman, K.F. 1994. Chiroptera: systematics. Handbook of Zoology, vol 8. $217 \mathrm{pp}$

Lim, B.K. 2009. Environmental assessment at the Bakhuis Bauxite Concession: Small Sized Mammal Diversity and Abundance in the Lowland Humid Forests of Suriname. The Open Biology Journal 2: 42-53.

Lim, B.K., Engstrom, M.D. 2001. Species diversity of bats (Mammalia: Chiroptera) in Iwokrama Forest, Guyana, and the Guianan subregion: implications for conservation. Biodiversity and Conservation 10: 613-657.

Lim, B.K.; Engstrom, M.D.; Timm, R.M.; Anderson. R.P.; Watson, L. C. 1999. First records of 10 bat species in Guyana and comments on diversity of bats in Iwokrama Forest. Acta Chiropterologica 1:179-190.

Lim, B.K.; Engstrom, M.D.; Bickham, J.W.; Patton, J.C. 2008. Molecular phylogeny of New World sheath-tailed bats (Emballonuridae: Diclidurini) based on loci from the four genetic transmission systems in mammals. Biological Journal of the Linnean Society 93: 189-209.

Lim, B.; Tavares, V.C. 2012. Species richness, biogeography, and conservation status of bats from the Guiana Subregion of northern South America. Ecotropica 18:105-118. 
Marques-Aguiar, S.A.; Aguila, M.V.; Aguiar, G.F.S.; Saldanha, N.; Silva-Junior, J.S. ; Rocha, M.M.B. 2003. Caracterização e perspectivas de estudo dos quirópteros da Estação Científica Ferreira Penna- município de Melgaço- PA. Idéias e Debates 6:1-3.

Martins, A.C.M.; Bernard, E.; Gregorin R. 2006. Inventários biológicos rápidos de morcegos (Mammalia, Chiroptera) em três unidades de conservação do Amapá, Brasil. Revista Brasileira de Zoologia 23:1175-1184.

McCarthy, T.J.; Ochoa J. 1991. The presence of Centronycteris maximiliani and Micronycteris daviesi (Chiroptera) in Venezuela. Texas Journal of Science 43:332-334.

Neuweiler, G. 2000. The biology of bats. New York: Oxford University Press.310 pp

Peters, S.L.; Malcolm, J.A.Y. R.; Zimmerman, B.L. 2006. Effects of Selective Logging on Bat Communities in the Southeastern Amazon. Conservation Biology 20:1410-1421

Rasweiler, J.J. 1982. The contribution of observations on early pregnancy in the little sac-winged bat, Peropteryx kappleri, to an understanding of the evolution of reproductive mechanisms in monovular bats. Biology of reproduction 27: 681-702.
Reis, N.R. 1984. Estrutura de comunidade de morcegos na região de Manaus, Amazonas. Revista Brasileira Biologia 44:247-54.

Sanborn, C.C. 1937. American bats of the subfamily Emballonurinae. Field Museum of Natural History, Zoological Series 24: 321-354.

Sikes, R.S.; Gannon, W.L.; The Animal Care and Use Committee of the American Society of Mammalogists. 2011. Guidelines of the American Society of Mammalogists for the Use of Wild Mammals in Research. Journal of Mammalogy 92: 235-253.

Simmons, N.B.; Handley, Jr. C.O. 1998. A revision of Centronycteris Gray (Chiroptera: Emballonuridae) with notes on natural history. American Museum Novitates 3239:1-28.

Simmons, N.B.; Voss, R.S. 1998. The mammals of Paracou, French Guiana: a neotropical lowland rainforest fauna. Part I. Bats. Bulletin of the American Museum of Natural History 273: 1-219.

Williams, S.L.; Genoways, H.H.; Groen, J.A. 1983. Results of the Alcoa Foundation-Suriname Expeditions. VII. Records of mammals from central and southern Suriname. Annals Carnegie Museum 52:329-36.

Recebido em 01/04/2015 Aceito em 15/05/2015 